\title{
27-Hydroxycholesterol induces macrophage gene expression via LXR-dependent and -independent mechanisms
}

\author{
Bo-Young Kim', Yonghae Son ${ }^{1}$, Hyok-rae Cho ${ }^{2, *}$, Dongjun Lee ${ }^{3}$, Seong-Kug Eo ${ }^{4}$, and Koanhoi Kim ${ }^{1, *}$ \\ ${ }^{1}$ Department of Pharmacology, School of Medicine, Pusan National University, Yangsan 50612, ${ }^{2}$ Department of Neurosurgery, Kosin University College of \\ Medicine, Busan 49267, ${ }^{3}$ Department of Convergence Medicine, School of Medicine, Pusan National University, Yangsan 50612, ${ }^{4}$ College of Veterinary Medi- \\ cine and Bio-Safety Research Institute, Jeonbuk National University, Iksan 54596, Korea
}

\section{ARTICLE INFO}

Received June 9, 2020

Revised September 24, 2020

Accepted December 22, 2020

*Correspondence

Hyok-rae Cho

E-mail:drchr@kosin.ac.kr

Koanhoi Kim

E-mail: koanhoi@pusan.ac.kr

Key Words

Gene expression

Liver $\mathrm{X}$ receptors

Macrophage

27-Hydroxycholesterol

\begin{abstract}
Hydroxycholesterol (27OHChol) exhibits agonistic activity for liver $\mathrm{X}$ receptors ( $L X R s)$. To determine roles of the $L X R$ agonistic activity in macrophage gene expression, we investigated the effects of LXR inhibition on the $27 \mathrm{OHChol-induced}$ genes. Treatment of human THP-1 cells with GSK 2033, a potent cell-active LXR antagonist, results in complete inhibition in the transcription of LXR target genes (such as LXRa and ABCA1) induced by $270 H C h o l$ or a synthetic LXR ligand TO 901317. Whereas expression of CCL2 and CCL4 remains unaffected by GSK 2033, TNF-a expression is further induced and $27 \mathrm{OHChol-induced} \mathrm{CCL3}$ and CXCL8 genes are suppressed at both the transcriptional and protein translation levels in the presence of GSK 2033. This LXR antagonist downregulates transcript levels and surface expression of CD163 and CD206 and suppresses the transcription of CD14, CD80, and CD86 genes without downregulating their surface levels. GSK 2033 alone had no effect on the basal expression levels of the aforementioned genes. Collectively, these results indicate that LXR inhibition leads to differential regulation of 27-hydroxycholesterolinduced genes in macrophages. We propose that $27 \mathrm{OHChol}$ induces gene expression and modulates macrophage functions via LXR-dependent and -independent mechanisms.
\end{abstract}

\section{INTRODUCTION}

Oxysterols are oxygenated derivatives of cholesterol. As compared to cholesterol, they contain an additional hydroxy, epoxide or ketone group in the sterol nucleus, and/or a hydroxyl group in the side chain [1]. 27-Hydroxycholesterol (27OHChol) is a sidechain oxysterol oxygenated at the 27th carbon atom of cholester$\mathrm{ol}$. This oxysterol is produced via oxidation by sterol 27-hydroxylase (CYP27A1), and metabolized via $7 \alpha$-hydroxylation for bile acid synthesis in the liver [1,2]. 27OHChol can also be formed in peripheral tissues either via enzymatic or non-enzymatic mechanisms $[2,3]$. The production of $27 \mathrm{OHChol}$ is enhanced in atherosclerotic lesions of the artery, and increasing amounts detected in lesions are associated with increasing macrophages $[4,5]$. The biological function of $27 \mathrm{OHChol} \mathrm{in} \mathrm{peripheral} \mathrm{tissues} \mathrm{differs} \mathrm{from}$ that in the liver. $27 \mathrm{OHChol} \mathrm{enhances} \mathrm{inflammation} \mathrm{and} \mathrm{triggers}$ an immune response by activating monocytes/macrophages. Following activation, they express chemokines, including chemokine (C-C motif) ligand (CCL) 2, CCL3 and chemokine (C-X-C motif) ligand (CXCL) 8 , and pattern recognition receptors that respond to the bacterial pathogen-associated molecular patterns [6-8]. 270HChol also induces molecules involved in T cell activation on the surface of monocytic cells [9]. Vascular smooth muscle cells and $\mathrm{T}$ cells, however, do not express such molecules in response to $27 \mathrm{OHChol}[10,11]$. These findings indicate that macrophages are the major cell type whose gene expression is influenced by (c) (i) (S)

This is an Open Access article distributed under the terms of the Creative Commons Attribution Non-Commercial License, which permits unrestricted non-commercial use, distribution, and reproduction in any medium, provided the original work is properly cited. Copyright $\odot$ Korean J Physiol Pharmacol, pISSN 1226-4512, elSSN 2093-3827
Author contributions: B-Y.K. and Y.S. performed all experiments. H-r.C. and K.K. designed the study. B-Y.K., D.L., and S-K.E. analyzed and interpreted data. B-Y. K., D.L., H-r.C., S-K.E., and K.K. drafted the manuscript. All authors review the manuscript. 


\section{OHChol.}

27OHChol is a functional liver X receptors (LXR) agonist [12]. LXR $\alpha$ (NR1H3) and LXR $\beta$ (NR1H2) are two isoforms of LXRs expressed with overlapping, but a distinctive pattern. LXR $\alpha$ is dominant in the liver and expressed primarily in the intestine, adipose tissue, and macrophages, whereas LXR $\beta$ is widely expressed [13-15]. Since LXRs are members of the nuclear hormone receptor superfamily of ligand-activated transcription factors, they exert their biological effects by controlling the expression of target genes [15]. Activation of LXRs with 27OHChol increases the transcription of LXR-responsive genes involved in cholesterol efflux, such as ABCA1 and ABCG1 in macrophages [12,14]. These findings indicate that $27 \mathrm{OHChol}$ induces gene expression via LXRs. However, it is unknown whether the LXR agonistic activity of $27 \mathrm{OHChol} \mathrm{is} \mathrm{involved} \mathrm{in} \mathrm{the} \mathrm{induction} \mathrm{of} \mathrm{genes} \mathrm{other} \mathrm{than}$ for cholesterol metabolism.

This study was therefore undertaken to determine the effects of GSK 2033, a potent cell-active LXR antagonist, on the transcription of 27OHChol-induced genes, including inflammatory and cell surface molecules as well as LXR target genes. Our results demonstrate that GSK 2033 differentially regulates the 27OHChol-induced genes in macrophages.

\section{METHODS}

\section{Cells and reagents}

The human THP-1 monocyte/macrophage cell line (ATCC, \#TIB-202) was purchased from the American Type Culture Collection (ATCC, Manassas, VA, USA). THP-1 cells were cultured in RPMI 1640 medium supplemented with 10\% fetal bovine serum (FBS) at $37^{\circ} \mathrm{C}$ in a humidified atmosphere of $5 \% \mathrm{CO}_{2}$. Penicillin $(50 \mathrm{U} / \mathrm{ml})$ and streptomycin $(50 \mu \mathrm{g} / \mathrm{ml})$ were added to prevent bacterial contamination. $27 \mathrm{OHChol}$ and antibodies against $\mathrm{LXR} \alpha / \beta, \mathrm{CD} 14, \mathrm{CD} 80$, and $\mathrm{CD} 86$ were purchased from Santa Cruz Biotechnology (Santa Cruz, CA, USA). GSK 2033 and TO 901317 were purchased from Sigma-Aldrich (St. Louis, MO, USA). Anti-ABCA1 antibody was purchased from Invitrogen (Eugene, OR, USA). Anti-CD163 antibody conjugated with FITC and anti-CD206 antibody conjugated with PE were purchased from BioLegend (San Diego, CA, USA).

\section{Reverse transcription-quantitative real-time polymerase chain reaction ( $R T-q P C R$ ) analysis}

Total RNA isolated were reverse-transcribed for $1 \mathrm{~h}$ at $42^{\circ} \mathrm{C}$ with $100 \mathrm{U}$ Moloney murine leukemia virus reverse transcriptase in a $10 \mu \mathrm{l}$ reaction volume, containing $50 \mathrm{mM}$ Tris- $\mathrm{HCl}(\mathrm{pH} 8.3$ at $25^{\circ} \mathrm{C}$ ), $55 \mathrm{mM} \mathrm{KCl}, 3 \mathrm{mM} \mathrm{MgCl}, 10 \mathrm{mM}$ DTT, $1 \mu$ g oligo (dT) 15 primers, $0.125 \mathrm{mM}$ each dNTP, and $40 \mathrm{U}$ RNase inhibitor. Subsequent qPCR was performed in triplicate using a LightCycler
96 Real-Time PCR System (Roche, Mannheim, Germany), as previously described [8]. Each $20 \mu \mathrm{l}$ reaction mixture consisted of 10 $\mu \mathrm{l}$ SYBR Green Master Mix, $2 \mu \mathrm{l}$ forward and reverse primers (10 $\mathrm{pM}$ each) of the gene to be quantified, and cDNA template. The thermal cycling conditions consisted of $95^{\circ} \mathrm{C}$ for $10 \mathrm{~min}$, followed by 45 cycles of $95^{\circ} \mathrm{C}$ for $10 \mathrm{sec}, 50^{\circ} \mathrm{C}$ for $10 \mathrm{sec}$, and $72^{\circ} \mathrm{C}$ for 10 $\mathrm{sec}$. The relative expression of each gene was calculated as the ratio to the GAPDH gene using the LightCycler 96 software (Version 1.1.0.1320; Roche). The primers used were as follows in Table 1.

\section{Western blot analysis}

Cell lysates were separated by 10\% SDS-PAGE, and resolved proteins were transferred to nitrocellulose membranes. After blocking for $1 \mathrm{~h}$ in $1 \%$ skim milk in TBS (pH 7.4) containing $0.05 \%$ Tween-20, membranes were incubated with antibodies against $\mathrm{LXR} \alpha / \beta, \mathrm{ABCA} 1$ or $\beta$-actin at $4^{\circ} \mathrm{C}$ overnight. Membranes were washed three times with $0.05 \%$ Tween 20/TBS for $10 \mathrm{~min}$ each and incubated for $1 \mathrm{~h}$ with HRP conjugated secondary Abs (1:5,000 dilution) at room temperature. After washing with $0.05 \%$ Tween 20/TBS, membranes were exposed to chemiluminescent detection reagents (Pierce ECL Western Blotting Substrate; Thermo Scientific, Rockford, IL, USA). Chemiluminescence images were captured by using an Amersham Imager 680 (GE Health-

Table 1. List of primers used in this study

\begin{tabular}{|c|c|c|}
\hline Gene & & Sequence \\
\hline \multirow[t]{2}{*}{$L X R \alpha$} & Forward & 5'-AAG CCC TGC ATG CCT ACG T-3' \\
\hline & Reverse & 5'-TGC AGA CGC AGT GCA AAC A-3' \\
\hline \multirow[t]{2}{*}{$A B C A 1$} & Forward & 5'-TGT CCA GTC CAG TAA TGG TTC TGT-3' \\
\hline & Reverse & 5'-CGA GAT ATG GTC CGG ATT GC-3' \\
\hline \multirow[t]{2}{*}{ CCL2 } & Forward & 5'-CAG CCA GAT GCA ATC AAT GCC-3' \\
\hline & Reverse & 5'-TGG AAT ССТ GAA CСC АCT ТСТ-3' \\
\hline \multirow[t]{2}{*}{ CCL3 } & Forward & 5'-AGT TCT CTG CAT CAC TTG CTG-3' \\
\hline & Reverse & 5'-CGG CTT CGC TTG GTT AGG A \\
\hline \multirow[t]{2}{*}{ CCL4 } & Forward & 5'-CTG GGT CCA GGA GTA CGT G \\
\hline & Reverse & 5'-GCG GAG AGG AGT CCT GAG TA-3' \\
\hline \multirow[t]{2}{*}{ CXCL8 } & Forward & 5'-TCT GCA GCT CTG TGT GAA GG-3' \\
\hline & Reverse & 5'-AAT TTC TGT GTT GGC GCA C \\
\hline \multirow[t]{2}{*}{$T N F-\alpha$} & Forward & 5'-CCC AGG GAC СТC ТСТ СТA ATC-3' \\
\hline & Reverse & 5'-ATG GGC TAC AGG CTT G \\
\hline \multirow[t]{2}{*}{ CD14 } & Forward & 5'-ACG CCA GAA CCT TGT GAG C-3' \\
\hline & Reverse & 5'-GCA TGG ATC TCC АCC TCT АCT G-3' ; \\
\hline \multirow[t]{2}{*}{ CD80 } & Forward & 5'-GCA GGG AAC ATC ACC ATC CA-3' \\
\hline & Reverse & 5'-TCA CGT GGA TAA CAC CTG AAC A-3' \\
\hline \multirow[t]{2}{*}{ CD86 } & Forward & 5'-GGA CTA GCA CAG ACA CAC GGA-3' \\
\hline & Reverse & 5'-CTT CAG AGG AGC AGC ACC AGA-3' \\
\hline \multirow[t]{2}{*}{ CD163 } & Forward & 5'-AAA AAG CCA CAA CAG GTC GC-3' \\
\hline & Reverse & 5'-CTT GAG GAA ACT GCA AGC CG-3' \\
\hline \multirow[t]{2}{*}{ CD206 } & Forward & 5'-TGA ATT GTA CTG GTC TGT CCT-3' \\
\hline & Reverse & 5'-CTG TGG TGC TGT GCA TTT ATC T-3' \\
\hline \multirow[t]{2}{*}{ GAPDH } & Forward & 5'-GAA GGT GAA GGT CGG AGT-3' \\
\hline & Reverse & 5'-GAA GAT GGT GAT GGG ATT TC-3' \\
\hline
\end{tabular}


care Life Scicences, Pittsburgh, PA, USA).

\section{Flow cytometric analysis}

THP- 1 cells were harvested by centrifugation at $200 \times \mathrm{g}$ for 5 min at room temperature and incubated for $2 \mathrm{~h}$ with antibodies against CD14, CD80 or CD86 (1:100 dilution) in the FACS buffer containing $2 \mathrm{mM}$ EDTA and $0.2 \%$ BSA in PBS. After washing with cold-PBS, cells were incubated for $1 \mathrm{~h}$ with Alexa Fluor 488-conjugated secondary antibodies (1:200 dilution) at $4^{\circ} \mathrm{C}$. Or the harvested cells were incubated with the fluorescent dyeconjugated antibodies (1:100 dilution) against CD163 or CD206 for $1 \mathrm{~h}$ at $4^{\circ} \mathrm{C}$. Cells were washed with cold-PBS, resuspended in $1 \%$ paraformaldehyde, and analyzed by flow cytometry.

\section{ELISA}

The amounts of CCL2, CCL3, CCL4, CXCL8, and TNF- $\alpha$ secreted in culture media were quantified using commercially available ELISA kits (R\&D Systems, Minneapolis, MN, USA), following the manufacturer's instructions.

\section{Statistical analysis}

Statistical analysis was performed via one-way analysis of variance, followed by Dunnett's multiple comparison test, using PRISM (version 5.0) (GraphPad Software Inc., San Diego, CA, USA). A p-value less than 0.05 ( $p<0.05)$ is considered to indicate a statistically significant difference.

\section{RESULTS}

\section{GSK 2033 inhibits the transcription of LXR target genes}

The human LXR $\alpha$ and ABCA1/ABCG1 are targets for regulation by LXR, and ligands for the receptor induce their expression in macrophages [12]. We investigated whether 27OHChol affects expression of the genes along with TO 901317, a synthetic LXR ligand. We observed levels of $L X R \alpha$ transcripts were elevated to 2.25- and 3.49-fold following stimulation with $27 \mathrm{OHChol}$ and TO 901317, respectively (Fig. 1A). Assessing the transcript levels of $A B C A 1$ revealed increases up to 1.31- and 8.04-fold by stimulation with 27OHChol and TO 901317, respectively (Fig. 1B). ABCG1 transcripts increased 4.33- and 28.5-fold after stimulation with 27OHChol and TO 901317, respectively (Supplementary Fig. 1). Investigating further whether expressions of $L X R \alpha$ and $A B C A 1 / A B C G 1$ genes were influenced by GSK 2033, a potent cell-active LXR antagonist [16], revealed that TO 901317- or 27OHChol-induced gene transcription of $L X R \alpha$ and $A B C A 1 /$ $A B C G 1$ was blocked in the presence of GSK 2033. In line with
A
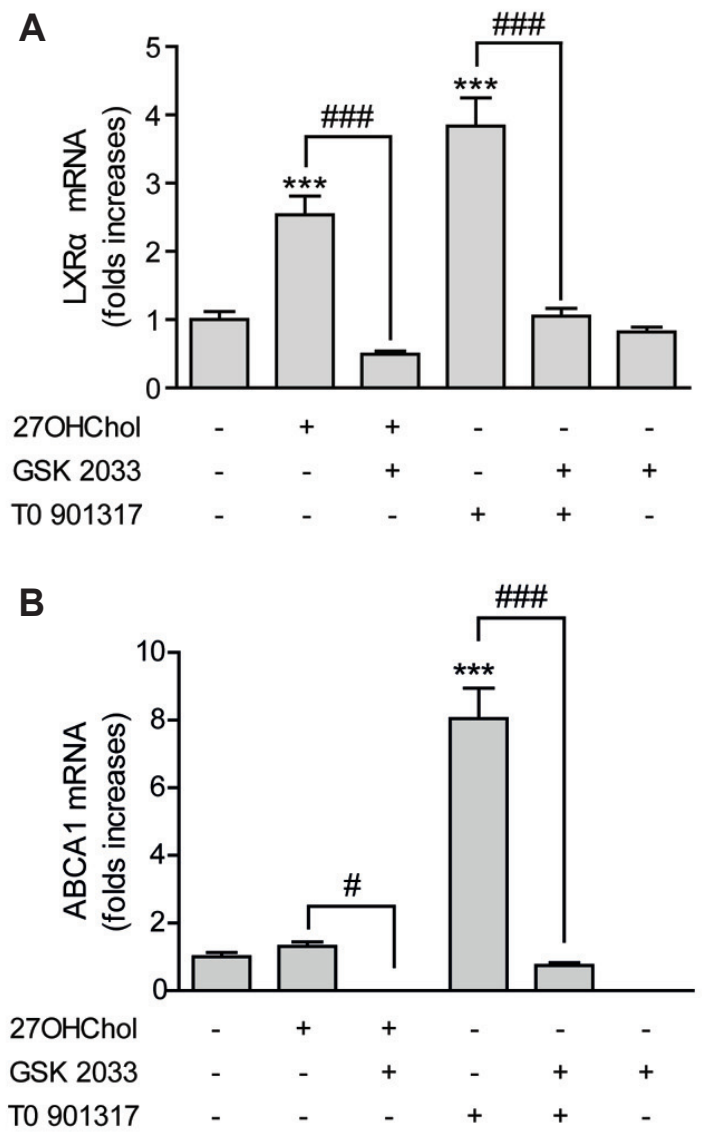

C

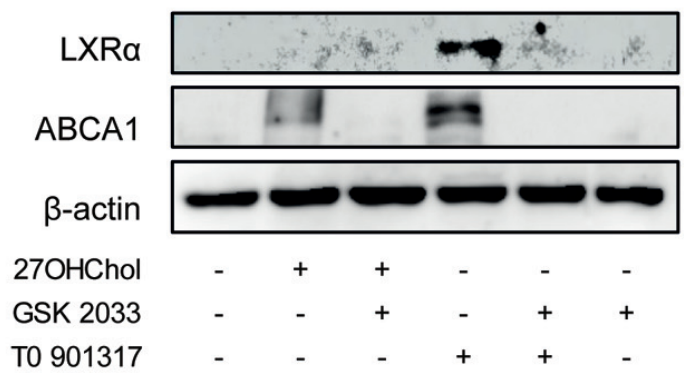

Fig. 1. Inhibitory effects of GSK 2033 on the transcription and protein translation of the LXRa and ABCA1 genes. THP-1 cells were serum-starved overnight and treated with GSK $2033(1 \mu \mathrm{M})$ for $2 \mathrm{~h}$. Cells were further stimulated with $27 \mathrm{OHChol}(2.5 \mu \mathrm{g} / \mathrm{ml})$ or TO $901317(1$ $\mu \mathrm{M})$ for $48 \mathrm{~h}$ in RPMI media supplemented with $10 \% \mathrm{FBS}$. The levels of LXR $\alpha$ (A) or ABCA1 (B) gene transcripts were assessed by real-time PCR. Data are expressed as the means \pm standard deviation $(n=3$ replicates for each group). LXRs, liver X receptors; FBS, fetal bovine serum. ${ }^{* *} \mathrm{p}<$ 0.001 vs. control; ${ }^{\# \# \#}$ < 0.001 vs. 270 HChol or TO 901317; ${ }^{*} p<0.05$ vs. 27OHChol or TO 901317. (C) LXR $\alpha$ and ABCA1 proteins were detected by Western blot analysis. Data represent a representative experiment (from 3 independent experiments).

the results of real-time PCR, 27OHChol and TO 901317 elevated protein levels of LXR $\alpha$ or ABCA1, which was completely inhibited by GSK 2033 (Fig. 1C). These results indicate that although less effective than the synthetic LXR agonist, 27OHChol induces 
expression of the LXR target genes, and the induction is impaired by GSK 2033.

\section{GSK 2033 suppresses 27OHChol-induced CCL3 gene}

27OHChol induces expression of $\mathrm{C}-\mathrm{C}$ chemokines, including CCL2, CCL3, and CCL4 [11]. We undertook to determine effects of GSK 2033 on the transcription of chemokines to understand the function of LXR inhibition in the induction of C-C chemokines. 27OHChol exposure elevated the levels of CCL2, CCL3, and CCL4 gene transcripts and their gene products (Fig. 2A and B). Although GSK 2033 did not significantly reduce expression of the CCL2 and CCL4 genes, the levels of CCL 3 transcripts and protein were profoundly decreased in the presence of GSK 2033.
The antagonist alone did not alter the transcript levels and secretion of the C-C chemokines. These results suggest that of the three C-C chemokines, GSK 2033 suppresses expression of the CCL3 gene alone.

\section{GSK 2033 displays opposite effects on $270 \mathrm{HChol}-$ induced CXCL8 and TNF- $\alpha$}

27OHChol as well as LXR agonists induces the CXCL8 and TNF- $\alpha$ genes which are involved in acute-phase inflammatory responses $[8,17,18]$. We investigated the roles of LXR agonistic activity of $27 \mathrm{OHChol} \mathrm{in} \mathrm{the} \mathrm{expression} \mathrm{of} \mathrm{CXCL8} \mathrm{and} \mathrm{TNF-} \alpha$. Treatment with GSK 2033 resulted in suppressing the transcription of CXCL8 gene, whereas the transcription of TNF- $\alpha$ further
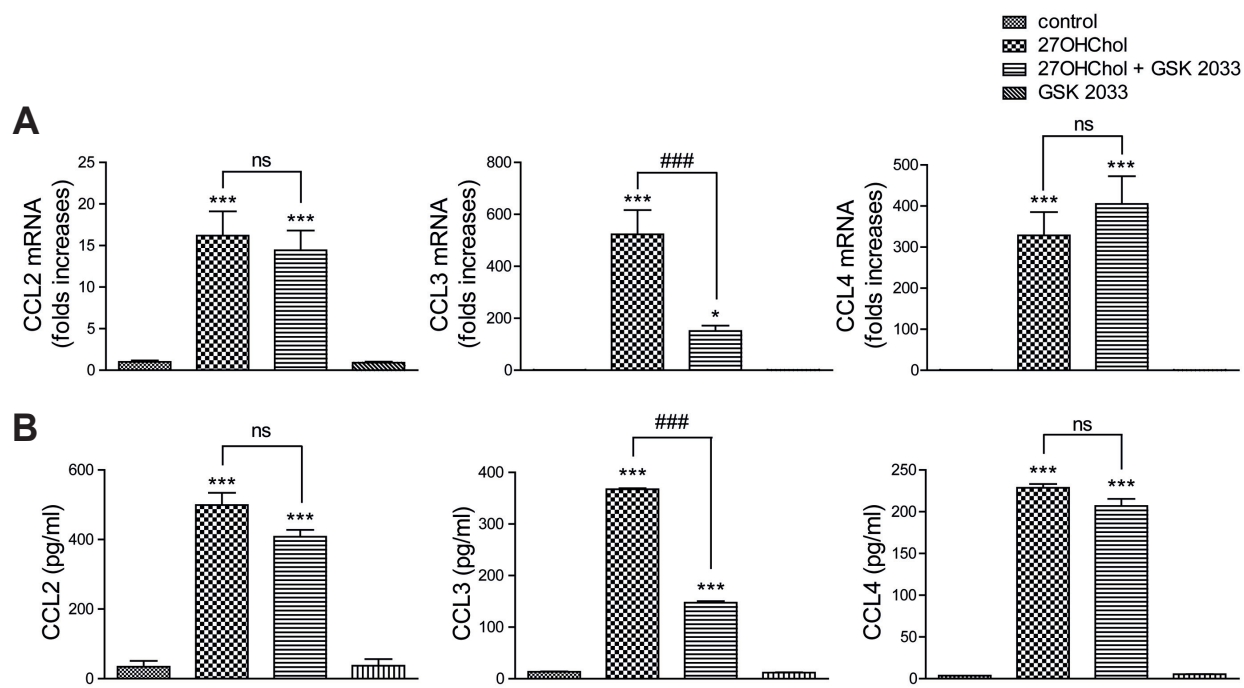

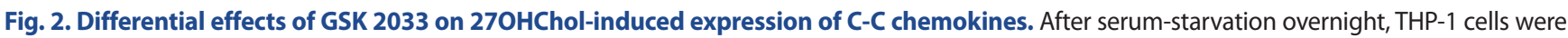
treated with GSK $2033(1 \mu \mathrm{M})$ for $2 \mathrm{~h}$ and stimulated with $27 \mathrm{OHChol}(2.5 \mu \mathrm{g} / \mathrm{ml})$ for $48 \mathrm{~h}$ in RPMI media supplemented with $10 \%$ FBS. (A) Levels of CCL2, CCL3, and CCL4 gene transcripts were assessed by real-time PCR. (B) The amounts of CCL2, CCL3, and CC4 proteins secreted in culture media were quantified by ELISA. Data are expressed as the means \pm standard deviation $(n=3$ replicates for each group). The results are representative of 3 independent experiments. FBS, fetal bovine serum. ${ }^{* * *} \mathrm{p}<0.001$ vs. control; ${ }^{*} p<0.05$ vs. control; $\#$ $p<0.001$ vs. $27 \mathrm{OHChol}$.
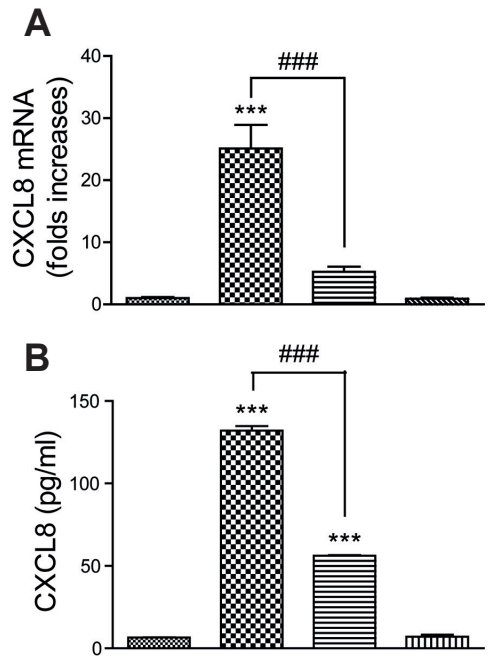
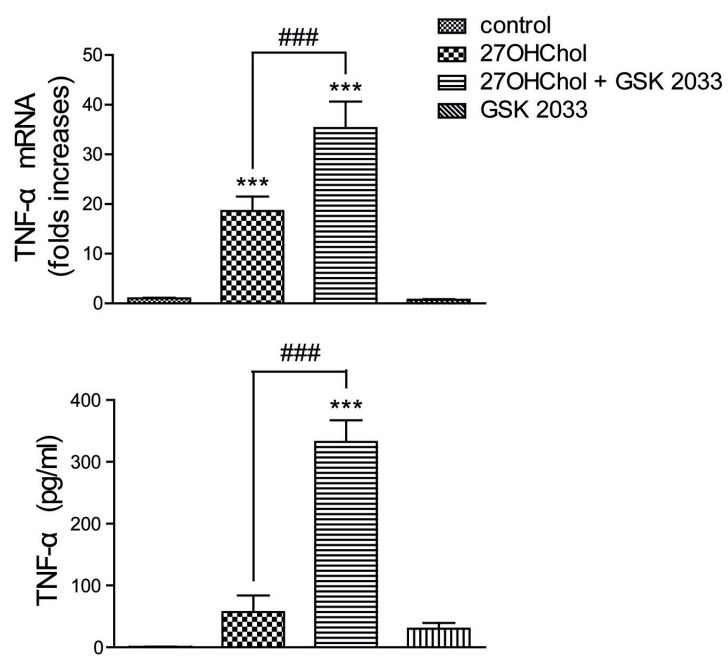

Fig. 3. Opposite effects of GSK 2033 on CXCL8 and TNF-a expression. Serumstarved THP-1 cells were treated with GSK $2033(1 \mu \mathrm{M})$ for $2 \mathrm{~h}$ and stimulated for $48 \mathrm{~h}$ with $27 \mathrm{OHChol}(2.5 \mu \mathrm{g} / \mathrm{ml})$. (A) Transcript levels of the CXCL8 and TNF- $\alpha$ genes were assessed by real-time PCR. (B) The amounts of CXCL8 and TNF- $\alpha$ proteins secreted in culture media were quantified by ELISA. Data are expressed as the means \pm standard deviation ( $\mathrm{n}=3$ replicates for each group). The results are representative of 3 independent experiments. The results are representative of 3 independent experiments. ${ }^{* * *} p<0.001$ vs. control; ${ }^{\# \#} \mathrm{p}<0.001$ vs. $27 \mathrm{OHChol}$. 
enhanced in the presence of GSK 2033 (Fig. 3A). We examined effects of GSK 2033 on CXCL8 and TNF- $\alpha$ secretion. GSK 2033 impaired CXCL8 production, but promoted secretion of TNF- $\alpha$ (Fig. 3B). These results suggest that LXR-agonistic activity of $27 \mathrm{OHChol} \mathrm{is} \mathrm{associated} \mathrm{with} \mathrm{a} \mathrm{repressive} \mathrm{effect} \mathrm{on} \mathrm{TNF-} \alpha$ expression.

\section{GSK 2033 downregulates the transcription of M1/M2 surface markers}

27OHChol affect levels of both M1 and M2 markers of macrophages [8]. We used GSK 2033 to estimate involvement of LXR agonistic activity in the induction of M1/M2 markers. $27 \mathrm{OHChol}$ increased levels of transcripts and surface expression of M2 markers of CD163 and CD206. Exposure to GSK 2033 resulted in suppressing the transcription of $C D 163$ and CD206 genes and downregulating their surface levels (Fig. 4A and B). We also investigated effects of GSK 2033 on M1 markers of CD80 and $C D 86$, along with $C D 14$. The transcription of three genes elevated by $27 \mathrm{OHChol} \mathrm{was} \mathrm{suppressed} \mathrm{in} \mathrm{the} \mathrm{presence} \mathrm{of} \mathrm{GSK} \mathrm{2033.} \mathrm{The}$ LXR antagonist, however, did not downregulate surface expression of CD14, CD80, and CD86 (Fig. 5A and B). These results suggest that LXR activation is required for $27 \mathrm{OHChol} \mathrm{to} \mathrm{induce}$ transcription of the M1/M2 markers and that they are differentially regulated at protein level after LXR inhibition.

\section{DISCUSSION}

The LXRs are members of the nuclear receptor superfamily that modulate metabolism, development, proliferation and inflammation through positive and negative regulation of gene expression [13]. LXRs have crucial functions in the regulation of immune responses. Activation of LXR with agonists downregu-
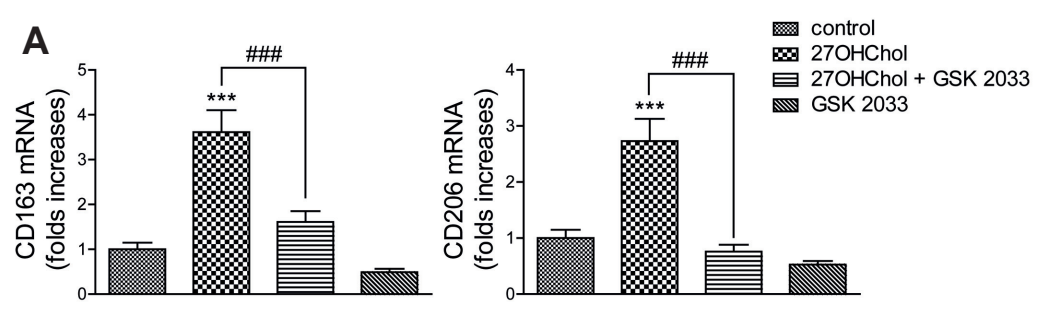

B Control

Control
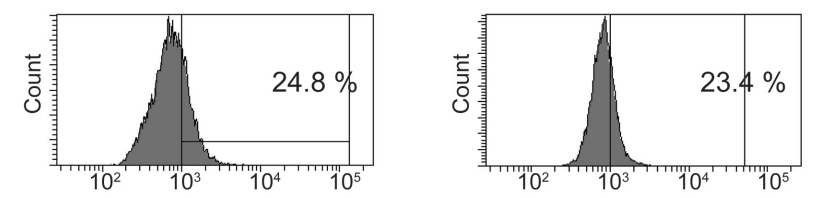

$27 \mathrm{OHChol}$

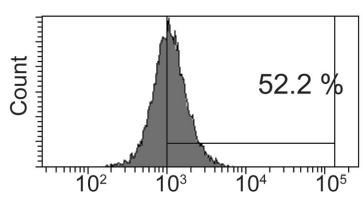

$27 \mathrm{OHChol}$

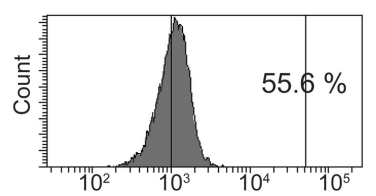

$27 \mathrm{OHChol}+$ GSK 2033
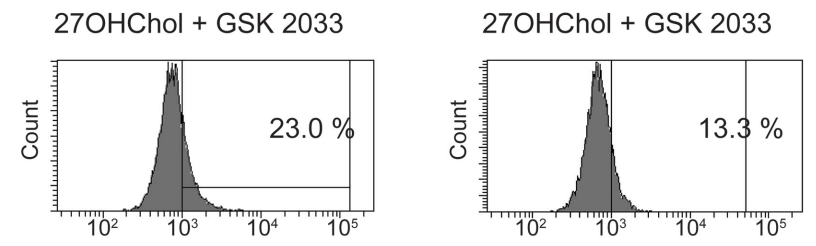

GSK 2033
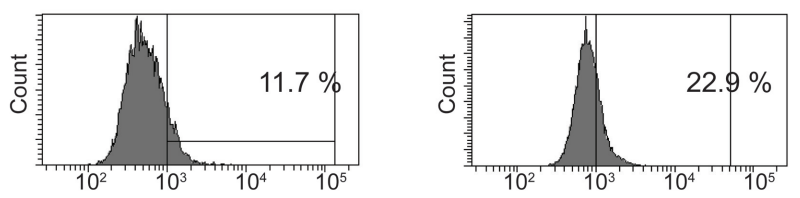

Fig. 4. Suppressive effects of GSK 2033 on M2 surface makers. Following serum-starvation, THP-1 cells were treated with GSK 2033 (1 $\mu$ M) for 2 $\mathrm{h}$ and stimulated with $27 \mathrm{OHChol}(2.5 \mu \mathrm{g} / \mathrm{ml})$ for $48 \mathrm{~h}$. (A) Transcript levels of the DC163 and CD206 genes were assessed by real-time PCR. Data are expressed as the means \pm standard deviation ( $n=3$ replicates for each group). (B) After immunostaining of CD163 and CD206 with fluorophore-conjugated Abs, cells were analyzed by flow cytometry. The results are representative of 3 independent experiments. ${ }^{* * *} p<0.001$ vs. control; ${ }^{\# \# \# ~} p<0.001$ vs. $27 \mathrm{OHChol}$. 

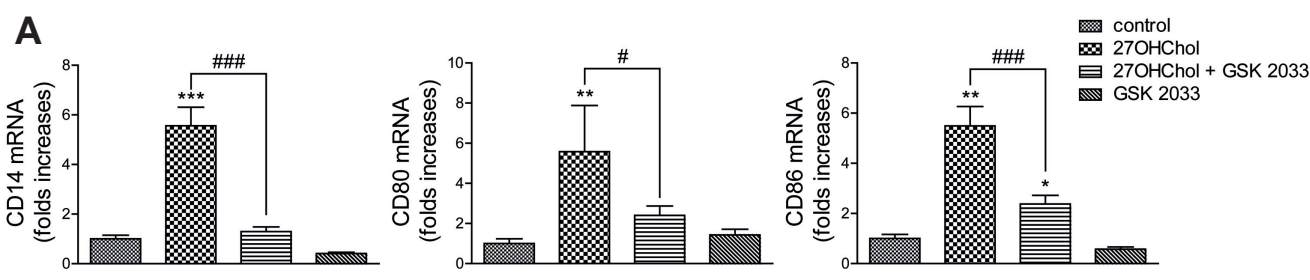

B Control

Control

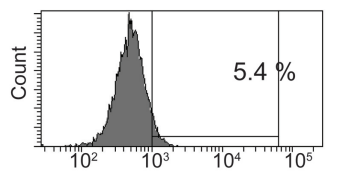

27OHChol

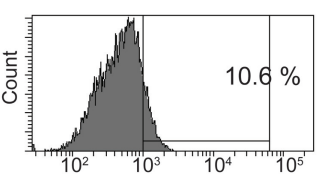

$27 \mathrm{OHChol} \mathrm{+} \mathrm{GSK} 2033$

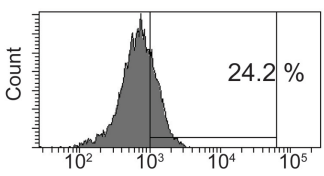

GSK 2033

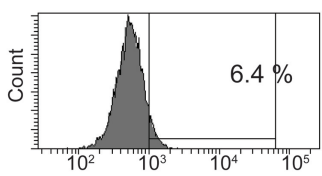

Control

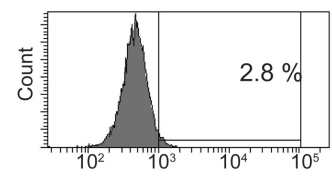

27OHChol

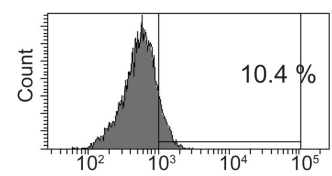

$27 \mathrm{OHChol}+$ GSK 2033

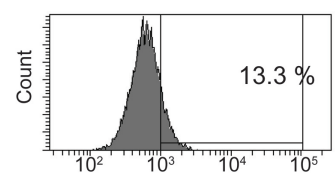

GSK 2033

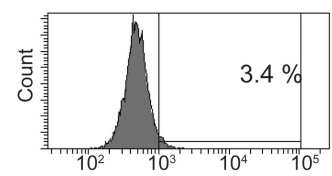

Fig. 5. Differential effects of GSK 2033 on expression of M1 surface markers. Serum-starved THP-1 cells were treated with GSK 2033 (1 $\mu$ M) for $2 \mathrm{~h}$, followed by stimulation with $27 \mathrm{OHChol}(2.5 \mu \mathrm{g} / \mathrm{ml})$ for $48 \mathrm{~h}$. (A) Transcript levels of the CD14, CD80, and CD86 genes were assessed by real-time PCR. Data are expressed as the means \pm standard deviation $(n=3$ replicates for each group). (B) After immunostaining of CD14, CD80, and CD86 with fluorophore-conjugated Abs, cells were analyzed by flow cytometry. The results are representative of 3 independent experiments. ${ }^{* * *} \mathrm{p}<0.001 \mathrm{vs}$. control; ${ }^{* *} \mathrm{p}<0.01$ vs. control; ${ }^{*} \mathrm{p}<0.05$ vs. control; ${ }^{\# \# \#} \mathrm{p}<0.001$ vs. $27 \mathrm{OHChol;}{ }^{*} \mathrm{p}<0.05$ vs. $27 \mathrm{OHChol}$.

lates the expression of inflammatory genes through a process known as transrepression, and several studies have demonstrated the anti-inflammatory activities of synthetic LXR agonists using different mouse models of inflammatory diseases [19-23]. Endogenous oxysterols, like 27OHChol, are known to activate LXRs [12]. It is evident that this oxysterol is a pro-inflammatory molecule activating macrophages. Activated cells increase cytokine production and upregulate cell surface molecules involved in the immune response $[7,9,10]$. The current study investigated whether LXR-agonistic activity of $27 \mathrm{OHChol} \mathrm{affects} \mathrm{the} \mathrm{cytokine}$ production and upregulates surface molecules after exposure to cell-active GSK 2033 [16], and thereby explored the biological functions of LXRs in macrophage activation.

$27 \mathrm{OHChol} \mathrm{induces} \mathrm{expression} \mathrm{of} \mathrm{diverse} \mathrm{genes} \mathrm{involved} \mathrm{in} \mathrm{lipid}$ metabolism, inflammation, and cell differentiation $[9,10,12]$. Consistent with previous reports $[12,14]$, we found that $27 \mathrm{OHChol}$ induces the LXR target genes of $L X R \alpha$ and $A B C A 1 / A B C G 1$ via LXR-dependent mechanisms. Besides, we have demonstrated that the LXR agonistic activity is involved in expression of CCL3, CXCL8, CD14, CD80, CD86, CD163 and CD206, since their gene transcription is inhibited by GSK 2033. The significantly reduced expression of pattern recognition receptors, such as CD14 and CD206, following LXR inhibition, agrees with previous study that has demonstrated that LXR activation impacts the functioning of immune cells to establish an immune response against pathogens [24-26]. The downregulation of CD80 and CD86 is in line with a previous study by Torocsik et al. that reported increased expression of these molecules in monocyte-derived dendritic cells after administration of LXR agonists [27]. Taken together, our results suggest that the LXR-agonistic activity of $27 \mathrm{OHChol} \mathrm{is} \mathrm{involved}$ in the complex effects of this oxysterol on immune cells.

27OHChol elevates transcripts of the LXR $\alpha$ gene without a noticeable increase in its gene product. TO 901317, however, enhances its expression at both mRNA and protein levels, as shown in Fig. 1. The differences can be caused by the nature of LXR agonistic activity. $27 \mathrm{OHChol} \mathrm{is} \mathrm{a} \mathrm{natural} \mathrm{LXR} \mathrm{agonist,} \mathrm{whereas} \mathrm{TO}$ 901317 is a synthetic one. TO 901317 displays a strong LXR agonistic activity and fully activates LXR signaling pathways [23]. In contrast, 27OHChol has a weak partial LXR agonistic activity [12]. Even though $27 \mathrm{OHChol} \mathrm{increases} \mathrm{the} \mathrm{level} \mathrm{of} L X R \alpha$ transcripts, 
it seems that the activation of additional factors is required for translation of the mRNA into protein.

Cell surface molecules such as CD14, CD80, CD86, CD163, and CD206 are specific markers whose levels are enhanced by 27OHChol on monocytic cells [8]. Among them, CD163 and CD206 belong to M2 polarization markers, and CD80, and CD86 to M1 markers [28]. The results of Figs. 4B and 5B imply that expression of CD163 and CD206 protein is positively regulated by the LXR pathway while CD14, CD80, and CD86 are negatively regulated at protein level in the presence of $27 \mathrm{OHChol}$. Collectively, these results suggest that LXR activity of $27 \mathrm{OHChol} \mathrm{is} \mathrm{also}$ involved in M2 polarization, which agrees with a previous study that reported that $27 \mathrm{OHChol} \mathrm{drives} \mathrm{M2} \mathrm{polarization} \mathrm{of} \mathrm{human}$ macrophages [29].

In summary, LXR inhibition with GSK 2033 leads to inhibited expression of CCL3 and CXCL8, but not of CCL2 and CCL4, enhanced TNF- $\alpha$ expression, and differential expression of M1/M2 markers on cell surface. We believe that the diverse effects of GSK 2033 are likely to be specific. GSK 2033 alone did not affect cell viability (Supplementary Fig. 2) and had no effect on the basal expression of the aforementioned genes. These results indicate that 27OHChol activates macrophages and affects immune cells via LXR-dependent and -independent mechanisms. Since 27OHChol induces inflammation and modifies immune responses by activating primarily monocytic cells, the molecular mechanisms underlying the cell type-specific effects of this oxysterol are still subject to further studies.

\section{ACKNOWLEDGEMENTS}

This research was supported by the Basic Science Research Program through the National Research Foundation of Korea (NRF) funded by the Ministry of Education (NRF-2019R1I1A3A01055344).

\section{CONFLICTS OF INTEREST}

The authors declare no conflicts of interest.

\section{SUPPLEMENTARY MATERIALS}

Supplementary data including two figures can be found with this article online at https://doi.org/10.4196/kjpp.2021.25.2.111.

\section{REFERENCES}

1. Schroepfer GJ Jr. Oxysterols: modulators of cholesterol metabolism and other processes. Physiol Rev. 2000;80:361-554.
2. Brown AJ, Jessup W. Oxysterols and atherosclerosis. Atherosclerosis. 1999;142:1-28.

3. Iuliano L. Pathways of cholesterol oxidation via non-enzymatic mechanisms. Chem Phys Lipids. 2011;164:457-468.

4. Carpenter KL, Taylor SE, van der Veen C, Williamson BK, Ballantine JA, Mitchinson MJ. Lipids and oxidised lipids in human atherosclerotic lesions at different stages of development. Biochim Biophys Acta. 1995;1256:141-150.

5. Garcia-Cruset S, Carpenter KL, Guardiola F, Stein BK, Mitchinson MJ. Oxysterol profiles of normal human arteries, fatty streaks and advanced lesions. Free Radic Res. 2001;35:31-41.

6. Heo W, Kim SM, Eo SK, Rhim BY, Kim K. FSL-1, a Toll-like receptor $2 / 6$ agonist, induces expression of interleukin- $1 \alpha$ in the presence of 27-hydroxycholesterol. Korean J Physiol Pharmacol. 2014;18:475480.

7. Kim SM, Lee SA, Kim BY, Bae SS, Eo SK, Kim K. 27-Hydroxycholesterol induces recruitment of monocytic cells by enhancing CCL2 production. Biochem Biophys Res Commun. 2013;442:159-164.

8. Lee J, Kim BY, Son Y, Giang DH, Lee D, Eo SK, Kim K. 4'-O-Methylalpinumisoflavone inhibits the activation of monocytes/macrophages to an immunostimulatory phenotype induced by 27 -hydroxycholesterol. Int J Mol Med. 2019;43:2177-2186.

9. Son Y, Kim SM, Lee SA, Eo SK, Kim K. Oxysterols induce transition of monocytic cells to phenotypically mature dendritic cell-like cells. Biochem Biophys Res Commun. 2013;438:161-168.

10. Kim SM, Kim BY, Eo SK, Kim CD, Kim K. 27-Hydroxycholesterol up-regulates CD14 and predisposes monocytic cells to superproduction of CCL2 in response to lipopolysaccharide. Biochim Biophys Acta. 2015;1852:442-450.

11. Kim SM, Kim BY, Lee SA, Eo SK, Yun Y, Kim CD, Kim K. 27-Hydroxycholesterol and 7alpha-hydroxycholesterol trigger a sequence of events leading to migration of CCR5-expressing Th1 lymphocytes. Toxicol Appl Pharmacol. 2014;274:462-470.

12. Fu X, Menke JG, Chen Y, Zhou G, MacNaul KL, Wright SD, Sparrow CP, Lund EG. 27-hydroxycholesterol is an endogenous ligand for liver X receptor in cholesterol-loaded cells. J Biol Chem. 2001;276:38378-38387.

13. Bookout AL, Jeong Y, Downes M, Yu RT, Evans RM, Mangelsdorf DJ. Anatomical profiling of nuclear receptor expression reveals a hierarchical transcriptional network. Cell. 2006;126:789-799.

14. Ignatova ID, Angdisen J, Moran E, Schulman IG. Differential regulation of gene expression by LXRs in response to macrophage cholesterol loading. Mol Endocrinol. 2013;27:1036-1047.

15. Willy PJ, Umesono K, Ong ES, Evans RM, Heyman RA, Mangelsdorf DJ. LXR, a nuclear receptor that defines a distinct retinoid response pathway. Genes Dev. 1995;9:1033-1045.

16. Zuercher WJ, Buckholz RG, Campobasso N, Collins JL, Galardi CM, Gampe RT, Hyatt SM, Merrihew SL, Moore JT, Oplinger JA, Reid PR, Spearing PK, Stanley TB, Stewart EL, Willson TM. Discovery of tertiary sulfonamides as potent liver $\mathrm{X}$ receptor antagonists. $J$ Med Chem. 2010;53:3412-3416.

17. Kim SM, Jang H, Son Y, Lee SA, Bae SS, Park YC, Eo SK, Kim K. 27-hydroxycholesterol induces production of tumor necrosis factor-alpha from macrophages. Biochem Biophys Res Commun. 2013;430:454-459.

18. Hong C, Walczak R, Dhamko H, Bradley MN, Marathe C, Boyadjian R, Salazar JV, Tontonoz P. Constitutive activation of LXR in mac- 
rophages regulates metabolic and inflammatory gene expression: identification of ARL7 as a direct target. J Lipid Res. 2011;52:531-539.

19. Joseph SB, Castrillo A, Laffitte BA, Mangelsdorf DJ, Tontonoz P. Reciprocal regulation of inflammation and lipid metabolism by liver $\mathrm{X}$ receptors. Nat Med. 2003;9:213-219.

20. Fowler AJ, Sheu MY, Schmuth M, Kao J, Fluhr JW, Rhein L, Collins JL, Willson TM, Mangelsdorf DJ, Elias PM, Feingold KR. Liver $\mathrm{X}$ receptor activators display anti-inflammatory activity in irritant and allergic contact dermatitis models: liver-X-receptor-specific inhibition of inflammation and primary cytokine production. J Invest Dermatol. 2003;120:246-255.

21. Heine G, Dahten A, Hilt K, Ernst D, Milovanovic M, Hartmann B, Worm M. Liver X receptors control IgE expression in B cells. J Immunol. 2009;182:5276-5282.

22. Park MC, Kwon YJ, Chung SJ, Park YB, Lee SK. Liver X receptor agonist prevents the evolution of collagen-induced arthritis in mice. Rheumatology (Oxford). 2010;49:882-890.

23. Terasaka N, Hiroshima A, Koieyama T, Ubukata N, Morikawa Y, Nakai D, Inaba T. T-0901317, a synthetic liver X receptor ligand, inhibits development of atherosclerosis in LDL receptor-deficient mice. FEBS Lett. 2003;536:6-11.

24. Bruhn KW, Marathe C, Maretti-Mira AC, Nguyen H, Haskell J, Tran TA, Vanchinathan V, Gaur U, Wilson ME, Tontonoz P, Craft N. LXR deficiency confers increased protection against visceral Leish- mania infection in mice. PLoS Negl Trop Dis. 2010;4:e886.

25. Korf H, Vander Beken S, Romano M, Steffensen KR, Stijlemans B, Gustafsson JA, Grooten J, Huygen K. Liver X receptors contribute to the protective immune response against Mycobacterium tuberculosis in mice. J Clin Invest. 2009;119:1626-1637.

26. Joseph SB, Bradley MN, Castrillo A, Bruhn KW, Mak PA, Pei L, Hogenesch J, O'connell RM, Cheng G, Saez E, Miller JF, Tontonoz P. LXR-dependent gene expression is important for macrophage survival and the innate immune response. Cell. 2004;119:299-309.

27. Töröcsik D, Baráth M, Benko S, Széles L, Dezso B, Póliska S, Hegyi Z, Homolya L, Szatmári I, Lányi A, Nagy L. Activation of liver X receptor sensitizes human dendritic cells to inflammatory stimuli. $J$ Immunol. 2010;184:5456-5465.

28. Zhou Y, Yoshida S, Kubo Y, Yoshimura T, Kobayashi Y, Nakama T, Yamaguchi M, Ishikawa K, Oshima Y, Ishibashi T. Different distributions of M1 and M2 macrophages in a mouse model of laserinduced choroidal neovascularization. Mol Med Rep. 2017;15:39493956.

29. Marengo B, Bellora F, Ricciarelli R, De Ciucis C, Furfaro A, Leardi R, Colla R, Pacini D, Traverso N, Moretta A, Pronzato MA, Bottino C, Domenicotti C. Oxysterol mixture and, in particular, 27-hydroxycholesterol drive M2 polarization of human macrophages. Biofactors. 2016;42:80-92. 